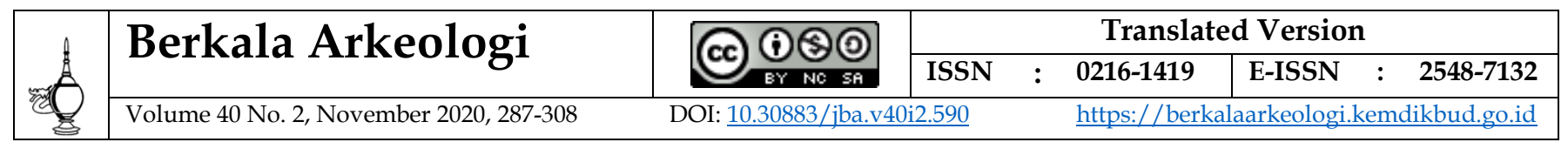

\title{
THE CHARACTERISTICS OF KUTA BATAGUH IN KAPUAS, CENTRAL KALIMANTAN
}

\section{KARAKTERISTIK KUTA BATAGUH DI KAPUAS, KALIMANTAN TENGAH}

\author{
Sunarningsih ${ }^{1}$, Hartatik ${ }^{1}$, Ida Bagus Putu Prajna Yogi ${ }^{1}$, \\ Unggul Prasetyo Wibowo ${ }^{2}$, Nugroho Nur Susanto', Restu Budi Sulistiyo ${ }^{1}$ \\ Regional Agency for Archaeological Research in South Kalimantan Province ${ }^{1}$ \\ Museum of Geology-Office of Geology, Bandung 2 \\ sunarningsih@kemdikbud.go.id
}

\begin{abstract}
ABSTRAK
Kuta Bataguh secara administratif berada di Kecamatan Bataguh dan Kapuas Timur, Kabupaten Kapuas, Kalimantan Tengah. Tujuan penelitian adalah untuk merekonstruksi karakteristik Kuta Bataguh. Penelitian ini bersifat deskriptif interpretif dengan penalaran induktif. Pengumpulan data menggunakan survei, ekskavasi, wawancara, dan studi pustaka. Analisis yang digunakan adalah analisis lingkungan, stratigrafi, artefaktual, ruang, dan analisis pertanggalan absolut. Kegiatan survei (permukaan dan udara) dan ekskavasi dilakukan di dalam dan di luar pagar benteng baik di arah muara maupun hulu Sungai Karinyau. Hasil penelitian memberi gambaran bahwa karakteristik Kuta Bataguh adalah tempat tinggal permanen yang luas dan dibelah oleh aliran sungai. Dengan berpatokan pada pola, fungsi, dan luasnya pemukiman ini, dapat diasumsikan bahwa penguasa lokal di Bataguh dalam organisasi sosial politiknya sudah setara dengan early state.
\end{abstract}

Kata kunci: Karakteristik; pemukiman berbenteng; Kuta Bataguh; Kalimantan Tengah

\section{ABSTRACT}

Kuta Bataguh is administratively located in Bataguh and East Kapuas Districts, Kapuas Regency, Kalimantan Tengah. The research aims to reconstruct the characteristics of Kuta Bataguh. This research is using interpretive-descriptive method with the inductive reasoning. Data collection used surveys, excavations, interviews, and literature study. The analysis included environmental, stratigraphic, artifactual, spatial, and absolute dating analysis. Survey (surface and aerial) and excavation activities were carried out inside and outside the fence, both downstream and upstream of the Karinyau River. The results illustrate that the characteristics of Kuta Bataguh are a large permanent settlement that is split by a river. The fortified settlement of Kuta Bataguh was the leader residence of Ngaju community group (as the center of power). By referring to the pattern, function and extent of this settlement, it can be assumed that the local authorities in Bataguh are on par with early state in their socio-political organization.

Keywords: Characteristics; fortified settlement; Kuta Bataguh; Central Kalimantan

Article Submitted : : :14-10-2019

Article Accepted : : :18-08-2020 


\section{INTRODUCTION}

The existence of kotta or kuta in the southeast Kalimantan region is known from Schwaner's expeditions conducted between 1843-1847 along the Barito River, Kapuas Murung River, and Kahayan River. Some of the expeditions mentioned kampongs (villages) and kotta (kuta) built on the banks of the river. In Dusun Ulu (now North Barito Regency) which is in the Barito River, there are five (5) villages and nine (9) kuta, while in Kapuas River there are nine (9) villages and twenty-six (26) kuta (Schwaner, 1853). Throughout the Kahayan Watershed there were 84 villages and 62 kuta recorded during the trip (Schwaner, 1854).

Kampung is an open settlement, while kotta is a settlement surrounded by fences. Kotta and the village have several buildings such as residences (long houses / betang, the size are varied depending on the number of residents), guest houses, and barns (storage) (Schwaner, 1854; Figure 1). Kampung and kuta are settlement of the Ot Danum and Ngaju people, which respectively have their own leaders. The size of their settlement is depending on their community group size.

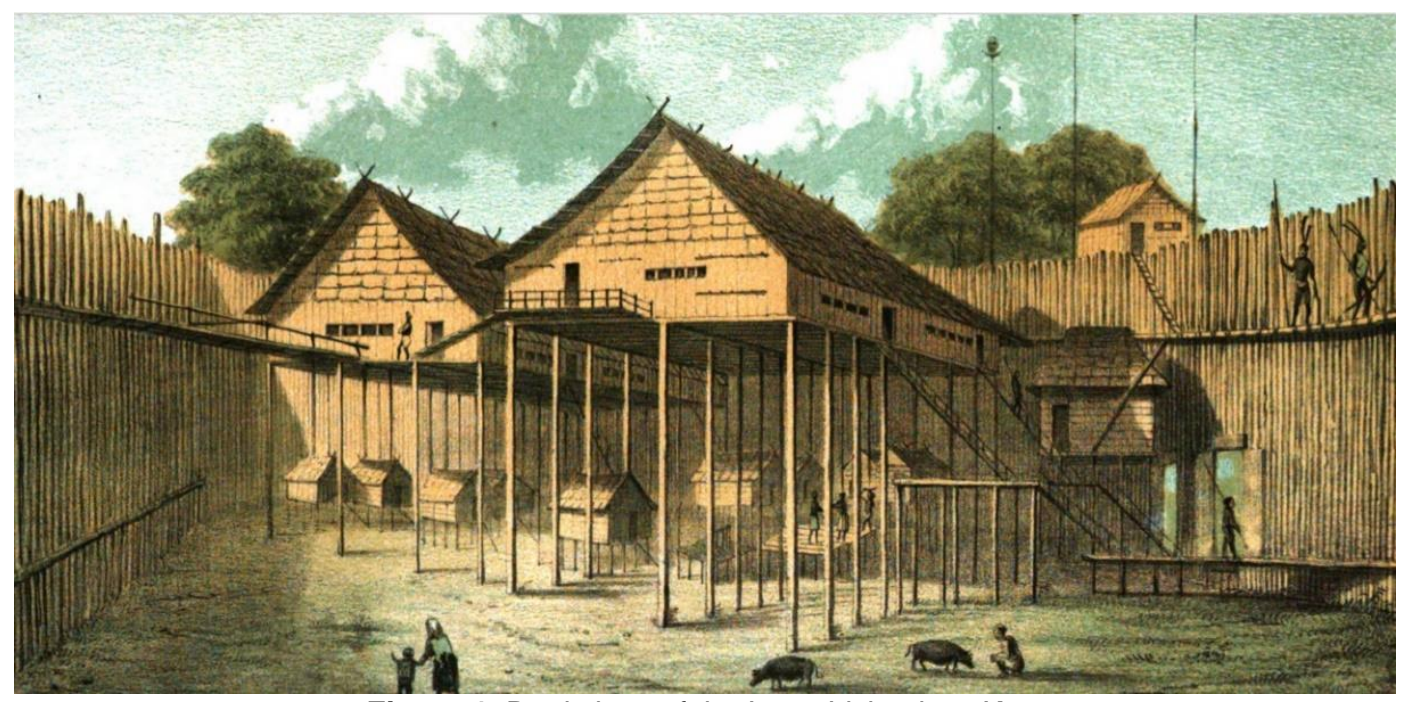

Figure 1. Depictions of the Inner Living in a Kuta

(Source: Schwaner, 1854)

Ngaju people now know the term kaleka, a former settlement area owned by one family (group), which is because it was inherited from ancestors. In kaleka there is an ancestral tomb that is believed to guarding the area, and is considered a sacred place (Rahu, et al, 2013). Usually the ancestral tomb is in a kuta, which is one area inside kaleka that is given a perimeter fence.

A kuta as a stronghold of the Ngaju community group is in a kaleka. Several kaleka in Hulu Kahayan that have been surveyed by the Regional Agency for Archaeological Research in South Kalimantan Province (Balai Arkeologi Kalimantan Selatan), namely Lawang Jori, Dambung Gunung, and Baseha (Sunarningsih, 2018a). Ngaju community fenceless settlements that have also been studied in Martaparu River (Barito tributary) is located at Cindai Alus (Sunarningsih, 2017a; Sunarningsih, 2018b).. Kaleka in Cindai Alus is a complete form of Ngaju group settlement without fences located at a swampy area, 
consisting of one large house, a small building (barn), two secondary burial buildings, and one building for ritual (Sunarningsih, 2018b).

Two kuta of the Ngaju people (mentioned in Schwaner expedition) are located in the upstream area, namely Kuta Hantapang (2016) and Kuta Mapot (2017), both located in Kahayan Watershed, and have been researched by Regional Agency for Archaeological Research in South Kalimantan Province. Kuta Hantapang is located on the banks of the Hantapang River (Rungan tributary), rectangular in shape with a length of 40 meters and a width of 25 meters. Inside the kuta there is a betang house measuring 8 meters wide and 20 meters long, and a secondary burial building (sandung) (Sunarningsih, 2017b).

The age of a pole inside Kuta Hantapang is ranging from 1300 to 1400 AD. In addition, there is a sample of charcoal that shows the youngest age with a difference of about 400 years. The results of this absolute dating is giving us an idea that the kuta was established in the 1300s, and the activity in kuta lasts until 1800 (Sunarningsih, 2017b).

Next, Kuta Mapot is in the same area as Kuta Hantapang, namely in Rungan Hulu Sub-District, Gunungmas Regency. Kuta Mapot is on the banks of the Lapan and Mapot Rivers, in a square form with a length of 36.5 meters and a width of 25 meters. Inside the kuta there is a house/ betang (size length of 27.4 meters and a width of 8.2 meters) and a sandung complete with sapundu and pantar pole. The perimeter fence is equipped with haramaung statue in the entrance gate and kamberawit (Sunarningsih, 2019).

Kuta Mapot's chronology is from the $4^{\text {th }}$ century AD to the $18^{\text {th }}$ century AD, indicating the sustainability of the settlement in this place. From the remaining samples of activity in the form of charcoal, fence posts, and hejan poles (house stairs) we received dating in the range of 300-600 AD. The youngest age comes from the sandung pole, from the $18^{\text {th }}$ century AD (1782-1797) (Sunarningsih, 2019). Kaleka and kuta that have been studied is a settlement of a small group of Ngaju built by a figure who becomes the leader.

Another larger and interesting kuta to research is Kuta Bataguh which is in the downstream area of Kapuas River Basin, precisely in Kapuas Murung tidal area. The name Bataguh is not mentioned in Schwaner's account of the twenty-six (26) kuta on the Kapuas River (Schwaner, 1853). Some of the names of kuta, at this time can still be known its existence, namely in the upstream area of Kapuas River (have not been studied).

The core area of Kuta Bataguh site is at $03^{\circ} 06^{\prime} 0^{\prime \prime}$ South Latitude and $114^{\circ} 22^{\prime} 4^{\prime \prime}$ East Longitude. The site environment is a tidal area located not far from Kuala Kapuas City (Figure 2), Kapuas Regency, Central Kalimantan Province. The vast land of the site is partly indigenous land, and others belong to the community. The existence of Bataguh site itself was known at the time of the creation of handil (irrigation rice field) around 1927, which struck into the rows of fence posts. Most of the fence posts of ironwood are then utilized by the community.

Massive looting in this site was happening in the 1980s, thousands of people came to the site in search of treasure. Many people found gold, beads, other equipment (from stone, wood, and metal), and left many digging holes until now. The location that is excavated for looting is around the Karinyau River that flows across $k u t a$ in the middle. The activity was eventually stopped by the authorities 
(Central Kalimantan Provincial Government and acted on its security by appointing a careakeeper for the site).

Furthermore, in the indigenous land a small-walled buildings known as Pesanggrahan Tujuh was built that were used as a place to store a wide range of artifacts both of stone (such as peestones) and wood (such as paddles and wooden containers), as well as natural stones collected from around the site. Until now, when people are holding ceremonies, they still visit the Pesanggrahan Tujuh. It appears that Kuta Bataguh is very different when compared to other kuta in the southeast Kalimantan region.

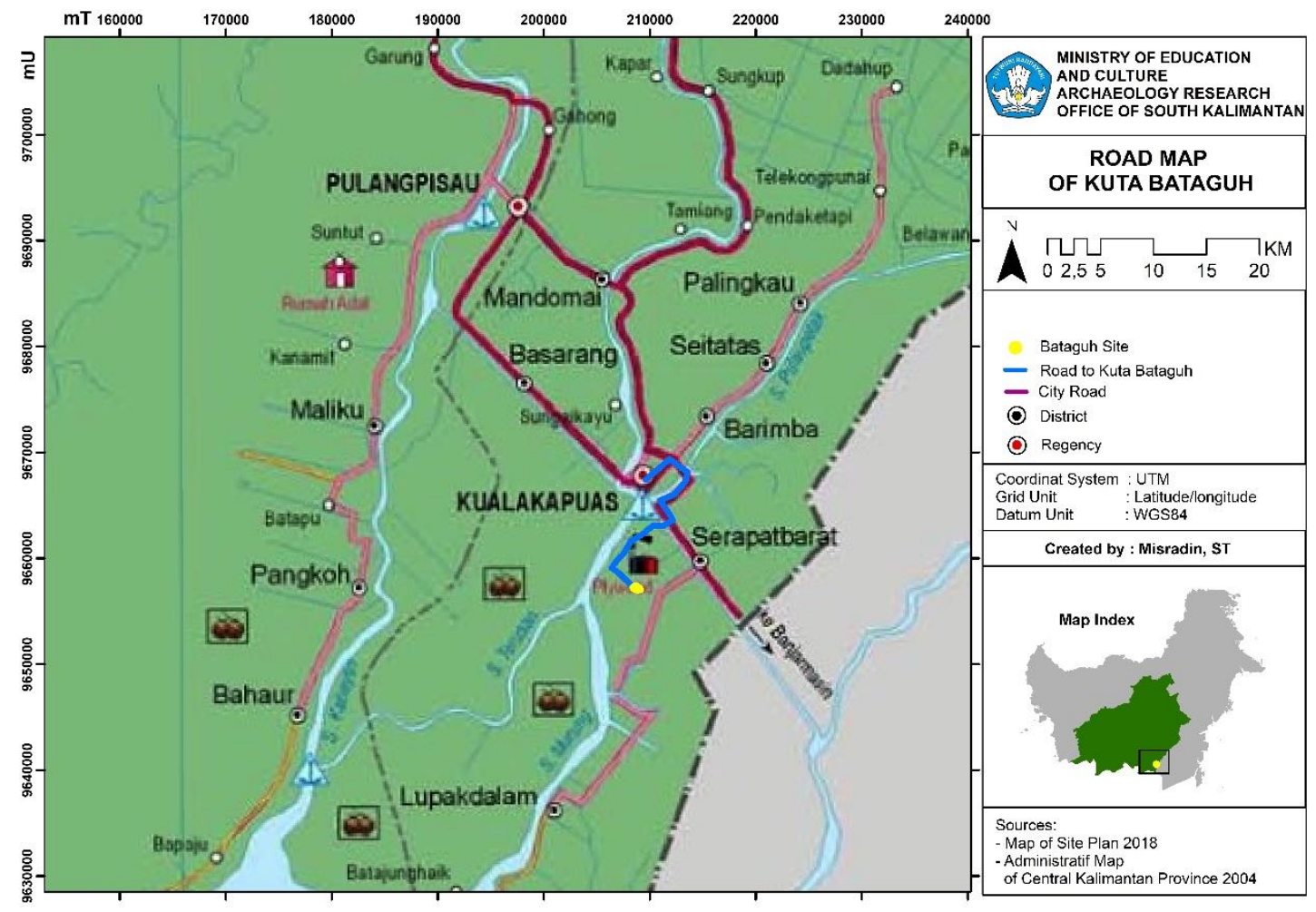

Figure 2. Location of Kuta Bataguh site

(Source: Regional Agency for Archaeological Research in South Kalimantan Province)

Some research has been done on Bataguh site, among others it is clear that Kuta Bataguh was led by Nyai Undang, who ruled around the $14^{\text {th }}$ century AD, and she is a part of the Ngaju community (Putro, et al. 2017). Bataguh has also been a hub for shipping and commerce, supported by archaeological data in the form of roving fences, boats, and other artifact data (Baier, 2002). Bataguh's location has also been linked to the kingdom of Tanjungpura, although it is later believed that the center of power is in the territory of West Kalimantan (Smith \& Smith, 2011). Both articles were relying more on missionaries news as sources who began entering the region in the 1600s. Regional Agency for Archaeological Research in South Kalimantan Province has conducted survey activities downstream of Kapuas River in 2009, but intensive research has only begun in 2017 to 2019. 
Considering the size of this site, the name Kotta / Kuta Bataguh which is not mentioned in Schwaner's report, and the fact that there is folklore that mentions the name of its leader by the title Nyai (female), raises questions since when the community began to know kuta as Bataguh, and even then became the name of the sub-district. The results of the historical research outlined in the book and the description in some of these articles have not mentioned the complete shape and size of kuta, as well as the distribution of the settlements of its people. Does Bataguh have the same form and community group as other kuta as mentioned not only by Schwaner but also the results of archaeological research in Kuta Mapot and Kuta Hantapang? Therefore, the research question in this study is on how the characteristics of Kuta Bataguh through the form, distribution of settlement and archaeological finds; about the strata of authority that lives inside the kuta; and the extent to which kuta people settlement can be traced back.

\section{METHODS}

In researching the culture of the past, we employed descriptiveinterpretive method with inductive reasoning (Hodder \& Hutson, 2003). Data collection is conducted by means of surveys, excavations, mapping, literary studies, and interviews (Renfrew \& Bahn, 2012; Simanjuntak et al, 2008). Surveys were conducted along the ancient (dead) river, namely Karinyau, both inside and outside the kuta fence. The survey activities aim to collect surface finds in the form of artifacts, features, and various phenomena of archaeological remains. Probing techniques are used to look for the existence of the remaining pillars of the house. Excavation activities are intended to collect data from cultural layers and to prove the existence of canals around kuta.

Interviews are conducted on figures and people around the site to collect data relating to what the public knows about the site, such as objects that have been found, stories related to the site ( oral history), what the public has done to the site, and knowledge of Bataguh site. Literary study was done to get data related to the concepts of settlement, religion, and social life of the Ngaju people.

Data analysis consists of artifactual analysis, stratigraphic analysis, absolute dating analysis, spatial analysis, and environmental analysis, (Simanjuntak et al,2008). Artifactual analysis is focused on morphological analysis to find out their function and origins (local or non-local). Stratigraphic analysis is carried out to find out the context of the findings in the soil layer. The results of this stratigraphic analysis are also used to assist in interpreting the existence of canals and when they were abandoned. Absolute dating analysis is done using charcoal and wood samples (the result of excavation activities) and sent to the laboratory. The results of the analysis are expected to clarify the chronology of the site.

Spatial analysis was done to find out the shape of kuta floor plan and the division of space that people do in their living activities. Observed variables are including the layout of buildings or the remains of buildings on the site, the height 
of the soil at the site (areas containing archaeological finds), rock sample data, and soil sample data (Bintarto \& Hadisumarno, 1991).

Environmental analysis was done by observing the environmental condition inside and outside Kuta Bataguh on the banks of the Karinyau River. This was done to know the carrying capacity of this site as a place to live, and its strategic position in a river trade path. Analysis is expected to provide answers about the character of the Bataguh site, especially in terms of the reason for the exploitation of Sungai Karinyau at that point.

Analysis of the results of the interview was conducted by filtering out themes or opinions fron the people. This filter then can be used to ensure the correctness of information and explanations of phenomenon found in the field, such as what they know about certain holes on the ground and pole findings.

\section{RESEARCH RESULTS}

Archaeological research on Kuta Bataguh which was conducted at the end of 2017 has shown us the shape and circumference fence of the fortification (Balai Arkeologi Kalimantan Selatan, 2017). In the 2018 research year we were able to know the spread/ distribution of house poles on the inside of the fortification fence (Balai Arkeologi Kalimantan Selatan, 2018). The following year, 2019, we were able to know the spread of house posts outside of the fence and the presence of roving canals (Balai Arkeologi Kalimantan Selatan, 2019). The results of the study through surveys, excavations, and interviews will be outlined below.

\section{Survey Results}

The survey was conducted to find out the shape of kuta and the spread of buildings, both the pole remains of the perimeter fence, and the house pole remains inside and outside that perimeter fence. The result has shown us that Kuta Bataguh is egg-shaped with a $3 \mathrm{~km}$ perimeter fence and is split by the Karinyau River flow. Outside of the perimeter fence, precisely downstream, there are the tributary of Karinyau river, namely Pantai/Alai River, Bataguh River, and Kupang River. The whole site is occupying $783,584.12 \mathrm{~m}^{2}$ area, and its circumference is 3,230.62 meters (Figure 3).

Ironwood poles are still found stuck in the ground and some poles are found above ground due to being lifted by heavy equipment during the extension of handil (artificial rivers for agricultural irrigation). The remains of wooden poles which are still stuck in the ground are found in high surfaces of land and form several groups of buildings. This group of eighteen (18) building remains are likely using stilts construction/ staging house.

Beside building remains that were found on high land surfaces, other building remains composed of ironwood were also found on the banks of the Karinyau River. It is interesting to note that building remains which are located on the banks of Karinyau River tributary are using several different types of wood. The large size of ironwood (with a diameter $\pm 40 \mathrm{~cm}$ ) forms three groups that are partly above the edge of the river section. Each group of buildings has access to 
the river, there are four groups of poles that function as a footbridge as well as a pier. The pole remains of the building on the southern banks of the Karinyau River are not much left, only holes of a former pole that is in the opposite direction from the group of buildings on the northern part of the bank. But the distance between those holes is far, so it is not yet known the number of buildings that exist on the south side of the riverbank.

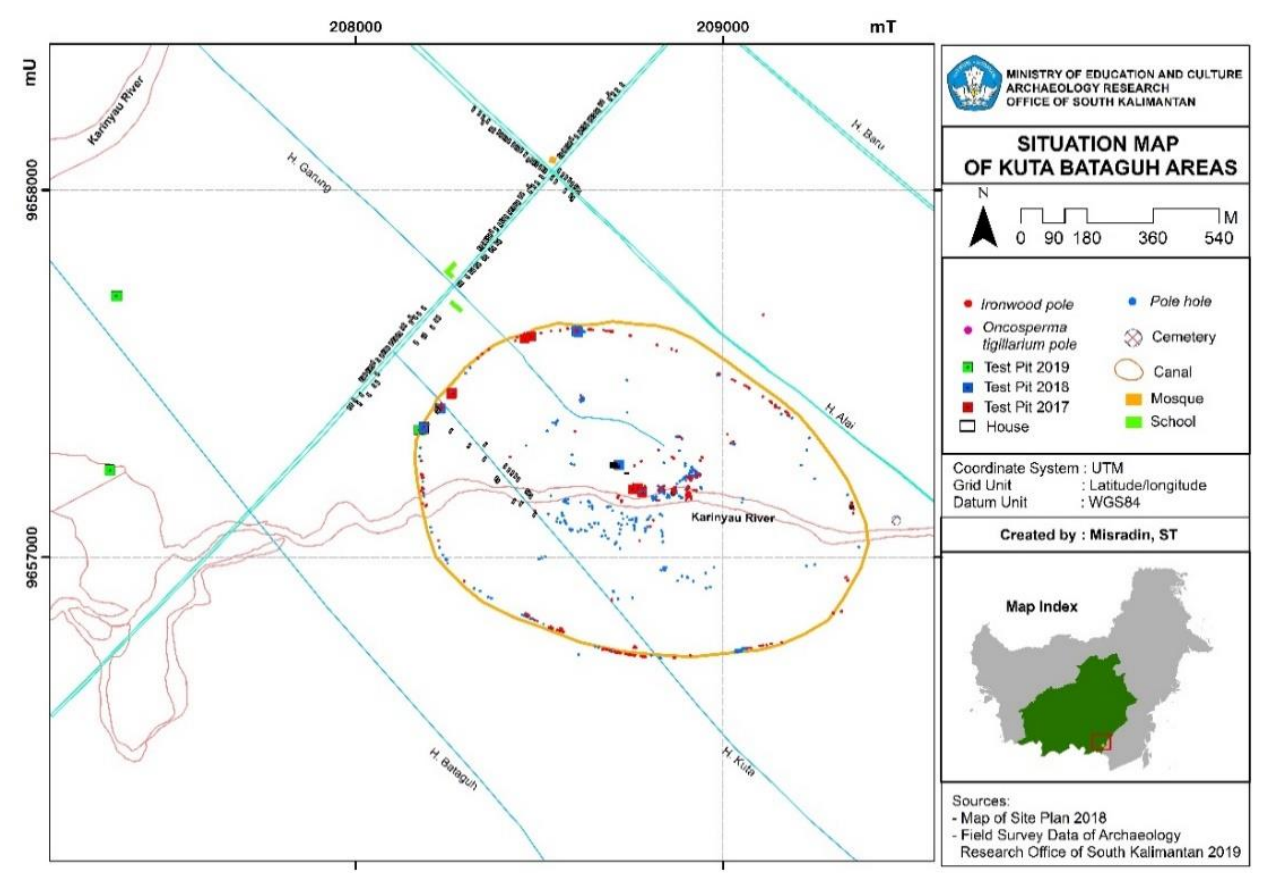

Figure 3. Situation Map of Kuta Bataguh

(Source: Regional Agency for Archaeological Research in South Kalimantan Province)

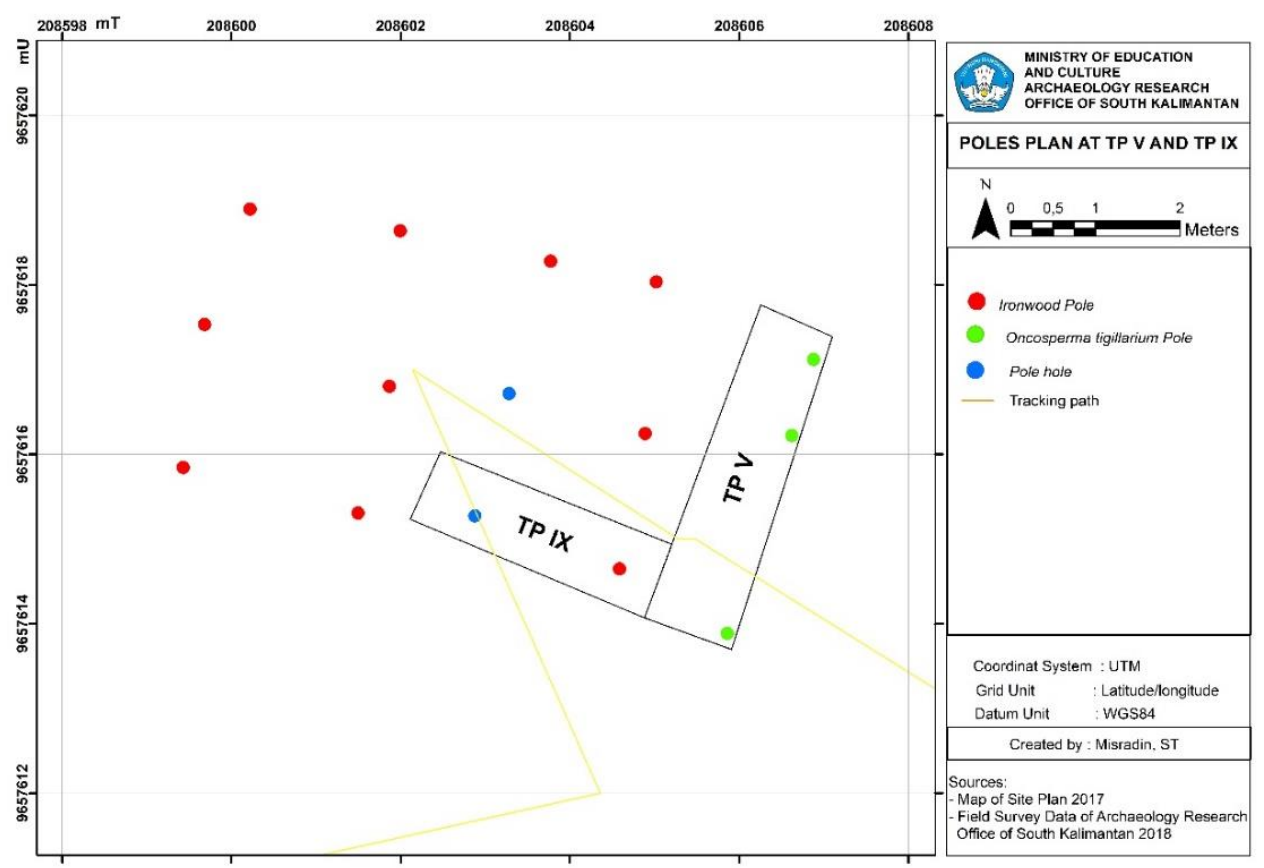

Figure 4. The Poles of the Guardian Buildings, on the Northern Fence of the Karinyau River (Source: Regional Agency for Archaeological Research in South Kalimantan Province) 
Poles that are still stuck on the ground were also found in several groups of small buildings that had twelve (12) ironwooden poles (Figure 4). This group of buildings are found near of the inner perimeter fence. Eight of these buildings which seem likely to be a building for guardian is on the north of the river, and four of them are located on the south of the river. The group of poles that are still intact with twelve (12) ironwood poles, are in two different places. Other than those two places, the poles are incomplete, some even we can only find the pole holes that form a square pattern.

In addition to the remains of house poles/ posts, some parts of the perimeter fence are also found still planted in the ground. Poles and house pole hole features are also found on the outside of the perimeter fence, along the flow of the Karinyau River both downstream and upstream. These features were spread downstream of the River Karinyau (which flow to the Kapuas Murung River) in three of their tributary streams. These three tributary rivers are not long and have now been cut off from the Karinyau River. The community revived the flow of the river (around 1927) by digging and making it handil and made them straight as a means of transportation and irrigation of rice fields. The community then built a stage house along the handil. The number of handil continues to grow in Bataguh area because this area is widely used as rice fields.

The edges of these three rivers that have now been turned into handil are difficult to know because they are covered by dense vegetation. In common cases, the old river paths are only recognizeable by the difference in of ground level. Regarding land functions, the changes are intensive in part of the land that led to the Kapuas Murung River. The utilization of the riverside area as a place to live by the people downstream makes the direction of the Karinyau River and its tributaries change. Outside the perimeter fence in the downstream area five settlement remains are also found. These five remains of settlement used to be on the banks of the Karinyau River, but in the present the river is no longer visible.

Upstream of Karinyau River the situation is different. The ancient river flow is still clearly visible in the rice fields and cut off by the handil path, both that led to the stream of Kapuas Murung River and Anjir Serapat River. Ancient river flow in the upstream area is easier to recognize because there are purun kudung vegetation as a marker. Pole remains of houses are also easily identifiable in the upstream area of the the Karinyau River, they are located not far from the perimeter fence. There were no poles found in the rice fields area.

Posts and raised house poles are also found to the southeast of the site, which is in the intersection of several handil with ancient river flows (Figure 5). The nearest people settlement as a part of the kuta was found in Handil Alai Darat. These nearest remains are indicated with post and former pole holes. Most post are found in Handil Baru almost 100s in number, made of selumbar wood (a type of swamp meranti), and their placing forms a pattern of buildings. Away to the southeast from the Handil Baru and Alai Darat, there are post remains in a location named Handil Perwira. Near the paved road to Tamban Sub-district, Handil Perwira became the point where the ancient river broke into three branches, namely towards Anjir Serapat, Barito River, and back towards Kapuas Murung River. Out of these three branches, Handil Batara and Handil Gardu have been surveyed. In Handil batara (Jangkit Village, towards Kapuas Murung River) one 
selumbar post and foreign ceramics collection which belongs to one of the residents were discoverde. In Handil Gardu (directing to Barito River, $12 \mathrm{~km}$ from Bataguh), post from selumbar wood was found.

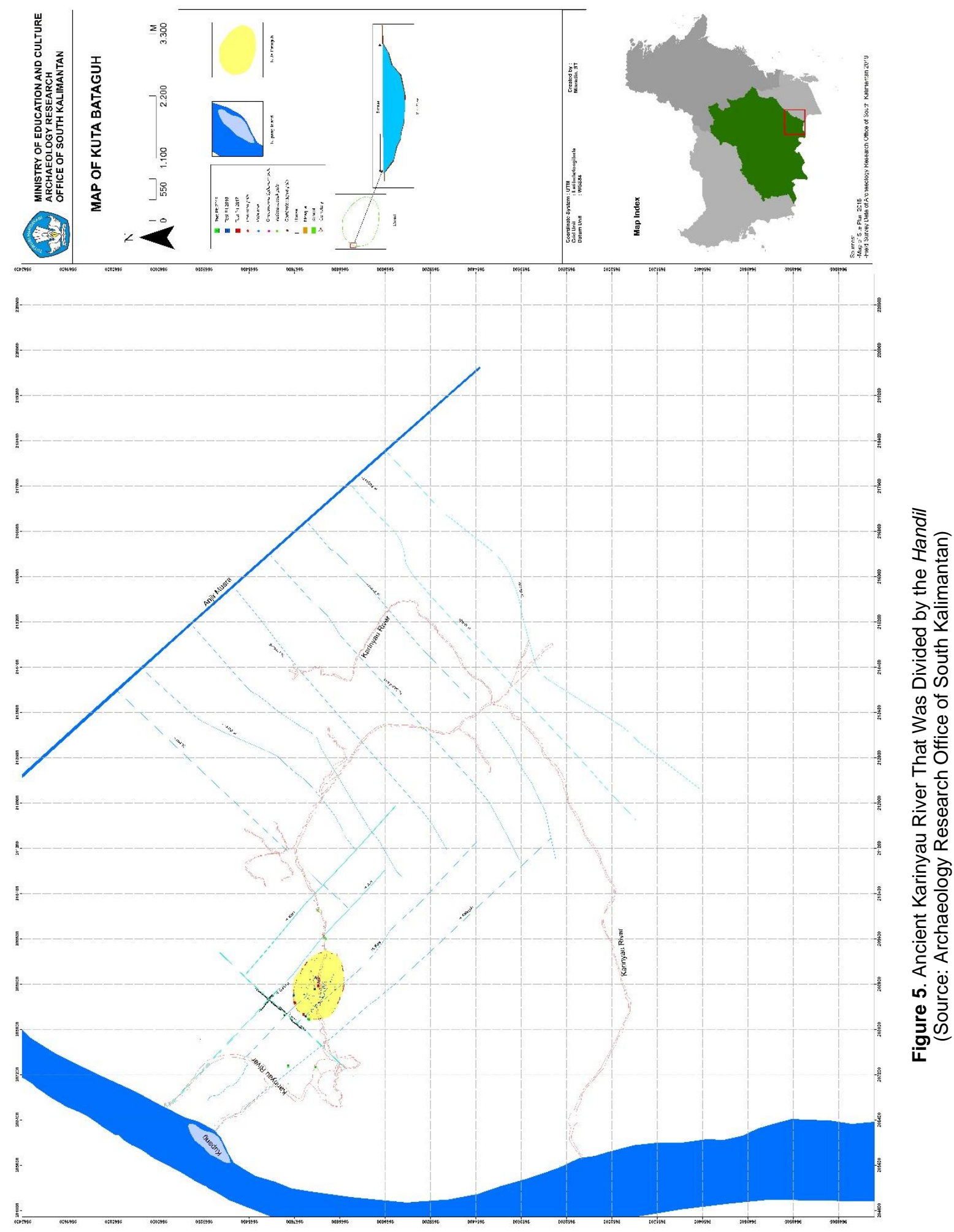




\section{Excavation Results}

Excavation activities are carried out in the fence section, in the area inside and outside the perimeter fence of kuta. Excavation activity in this tidal area is constrained by the appearance of water when the excavation box has reached a depth above $50 \mathrm{~cm}$. The excavation results can be seen in the following table.

Table 1. Testpit Inside the Perimeter Fencing

\begin{tabular}{|c|c|c|}
\hline Sector / Year & TP & Findings \\
\hline Handil Kota (2017) & TP I & $\begin{array}{l}\text { The wooden pole section of the fence post (?) which continues } \\
\text { to the next layer of wooden tools, pottery fragment }\end{array}$ \\
\hline Handil Kota (2017) & $\begin{array}{c}\text { TP } \\
\text { II }\end{array}$ & $\begin{array}{c}2 \text { ironwood posts part of the pole with a kalang sunduk } \\
\text { construction, continue to the next layer }\end{array}$ \\
\hline Handil Kota (2017) & $\begin{array}{l}\text { TP } \\
\text { III }\end{array}$ & $\begin{array}{c}1 \text { ironwood post part of the pole with a kalang sunduk } \\
\text { construction, continues to the next layer }\end{array}$ \\
\hline Handil Kota (2017) & $\begin{array}{l}\text { TP } \\
\text { IV }\end{array}$ & $\begin{array}{c}3 \text { ironwood posts in a standing position (diameter } 33 \mathrm{~cm} \text { (two } \\
\text { posts) and } 39 \mathrm{~cm} \text { ), and one fallen post; wood fragments, } \\
\text { wooden tools, burning clay }\end{array}$ \\
\hline $\begin{array}{l}\text { Benteng Pagar/ } \\
\text { Perimeter Fence } \\
\text { (2018) }\end{array}$ & $\begin{array}{l}\mathrm{TP} \\
\mathrm{V} \\
\text { and } \\
\mathrm{IX}\end{array}$ & $\begin{array}{l}\text { Wood fragments (sumpung); ironwood post (up to layer B) } \\
\text { Wood fragments (sumpung, halayung, ironwood); pottery } \\
\text { fragments; resin, halayung post (nibung) }\end{array}$ \\
\hline $\begin{array}{l}\text { Benteng Pagar/ } \\
\text { Perimeter Fence } \\
\text { (2018) }\end{array}$ & $\begin{array}{l}\text { TP } \\
\text { VI }\end{array}$ & $\begin{array}{l}\text { Ironwood fragments, clear red glass beads; ironwood post (up to } \\
\text { layer B) } \\
\text { Ironwood fragments, galam wood, resin, pottery fragments, } \\
\text { charcoal }\end{array}$ \\
\hline $\begin{array}{l}\text { Benteng Pagar/ } \\
\text { Perimeter Fence } \\
\text { (2018) }\end{array}$ & $\begin{array}{l}\text { TP } \\
\text { VII }\end{array}$ & $\begin{array}{c}\text { Two ironwood post that have holes at their top, this posts } \\
\text { continue until the last layer (final depth) }\end{array}$ \\
\hline $\begin{array}{l}\text { Benteng Pagar/ } \\
\text { Perimeter Fence } \\
\text { (2018) }\end{array}$ & $\begin{array}{l}\text { TP } \\
\text { VIII }\end{array}$ & $\begin{array}{l}\text { Two ironwoods in a standing position, in an incomplete } \\
\text { condition, with a hole at the top of the wood. } \\
\text { Two ironwoods in a fallen position, their condition is not intact, } \\
\text { has a hole at the top of the wood. Some of the wood looks brittle } \\
\text { (lots of cracks on the surface of the wood) }\end{array}$ \\
\hline
\end{tabular}

Table 2. Testpit Outside the Perimeter Fencing

\begin{tabular}{|c|c|c|}
\hline Sector / year & TP & Findings \\
\hline Pesanggrahan (2017) & TP I & Pottery fragments \\
\hline Pesanggrahan (2017) & TP ॥ & Pottery fragments \\
\hline Pesanggrahan (2017) & TPIII & Pottery fragments in \\
\hline Pesanggrahan (2018) & TP IV & Pottery fragments, wood fragments, charcoal, resin \\
\hline Pesanggrahan (2018) & TP V & - \\
\hline Pesanggrahan (2018) & TP VI & $\begin{array}{c}\text { Pottery fragments, wood fragments, charcoal, } \\
\text { charcoal collapsed ironwood cut in half and have holes on } \\
\text { the surface }\end{array}$ \\
\hline Pesanggrahan (2018) & TP VII & $\begin{array}{l}\text { Pottery fragments, wood fragments by workmanship, } \\
\text { charcoal, resin; Findings of charcoal, fallen ironwood cut } \\
\text { in half and have holes in the surface }\end{array}$ \\
\hline
\end{tabular}

Source: Results of research by Regional Agency for Archaeological Research in South Kalimantan Province 2017 and 2018 
Table 3. Testpit on the Outside of the Perimeter Fence

(along the Karinyau river and perimeter canals)

\begin{tabular}{|c|c|c|}
\hline Sector / year & Box & Findings \\
\hline Handil Bataguh (2019) & TP 1 & Fragments of pottery, resin, charcoal, and ceramic \\
\hline Handil Bataguh (2019) & TP 2 & Charcoal and pottery fragments \\
\hline Handil Bataguh (2019) & TP 3 & Fragments of pottery, resin, charcoal, and ironwood \\
\hline Handil Bataguh (2019) & TP 4 & Pottery and resin fragments; pieces of tumih woods \\
\hline Handil Alai Darat (2019) & TP 1 & Fragments of pottery; wood, and nipah fruit \\
\hline Handil Alai Darat (2019 & TP 2 & $\begin{array}{l}\text { Pottery fragments, ironwood chips, charcoal, and bones. } \\
\text { Square Ironwood posts; beads, iron tools, ceramic } \\
\text { fragments, ironwood chips, charcoal }\end{array}$ \\
\hline $\begin{array}{l}\text { Kanal (2019), long } \\
\text { rectangular shape } \\
\text { (across the canal) }\end{array}$ & TP 1 & Pottery fragments and wood fragments \\
\hline $\begin{array}{l}\text { Kanal (2019), long } \\
\text { rectangular shape } \\
\text { (across the canal) }\end{array}$ & TP 2 & Wood fragments \\
\hline
\end{tabular}

Excavations have been carried out at seven different locations (in 2017, 2018, and 2019) to find out the remains of the kuta community (inside the fortification). Cultural remains in the form of pottery fragments, beads (one translucent red glass bead (new)), and wooden tools, were found around the building posts next to the perimeter fence. Their settlement locations are scattered inside the fortification, on both sides of the river. The pottery fragments are difficult to identify their variety of shapes, but the condition indicates that the pottery is of low quality, burned in open space. The artifact bearing soil layer is the second layer, namely the layer of clay (depth less than $50 \mathrm{~cm}$ ). At that $50 \mathrm{~cm}$ depth, the excavation must be stopped because the box was submerged with water. The first layer (top) in this box is sandy clay mixed with humus ( $\pm 20 \mathrm{~cm}$ thick) and the second layer (clay) is $\pm 30 \mathrm{~cm}$ thick.

The artifacts from the excavation box were not as many as those found by the residents (which can still be re-documented in the study). Various artifacts found by the residents were wooden tools in various forms, stone tools, jewelry (made of precious metals, both intact and fragmentary); beads, and metal tools. Since those artifacts were found by the residents, we are hardly able to put them in stratigraphy context.

House posts are planted as deep as 4 meters from the ground level to ensure their stability. These posts are also supported by using kalang sunduk, placed not far from the ground level, at a depth of $\pm 50 \mathrm{~cm}$. The number of these house buildings is not yet known for certain, but the most populous concentration is right in the middle, on the banks of the Karinyau River and its tributaries. The common material of the house pole is ironwood, another type of wood namely belangiran or also known as red balau (Shorea balangeran), selumbar wood (Vatica rassak), tumih wood (Combretocarpus rotundatus)), halayung/ nibung wood (Oncosperma tigillarium), and supang wood (shorea pachyphylla). This type of wood 
(other than ironwood) grows in peatlands (swamps) (Akbar, 2012; Maimunah, 2014). From the existence of house poles and fences left on the site, it can be said that the community did bring ironwood logs from the upstream area, while other types of wood came from around the site because they grew on peatland. It can be concluded that the economic value of ironwood is higher than that of other types of wood.

Artifacts in the area outside of the perimeter fence (excavated in 2019), along the river, among others are fragments of pottery, foreign ceramics, beads (one white glass bead), and wooden tools. Important to note that foreign ceramic fragments were have not been found inside the perimeter fence. The community (or looters in the 1980s) gave the same information that foreign ceramic fragments were not found when digging on the inside of the fence. Fragmented foreign ceramics found from the excavation boxes (outside of the fence) are not numerous, while ceramics found by many residents are still intact. Most of these foreign ceramics can be dated back to Qing Dynasty of China (18 $18^{\text {th }} 19^{\text {th }}$ century).

The test-pit to prove the existence of roving canal is in the Handil Kota sector, at the point of $3^{0} 05^{\prime} 48.5^{\prime \prime}$ South Latitude; 114022' 28.6" East Longitude. This excavation box was open using a $1 \times 4$ meters trench system, crossing the canal flow. The test pit had many ironwood fragments and only a few pottery fragments. The canal indication area can be seen by observing the position of groundwater at the highest tide, which the water bodies have turned into a peat sediment layer. The thickness of the peat deposits from the groundwater position in the test pit ranges from $40-50 \mathrm{~cm}$. The rate of peat formation is influenced by many factors, especially local environmental conditions, but in general, the rate of peat formation is not more than $3 \mathrm{~mm}$ per year in primary forest conditions (Lucas, 1982). If the condition of the vegetation in the canal area is considered constant with the calculation of peat formation of about $3 \mathrm{~mm}$ per year and the largest number of thickness taken is $50 \mathrm{~cm}$, it can be estimated that the waters in the canal had begun to disappear and had been covered by peat deposits since approximately 166 years ago. Dated back from 2019, the last waters in the canal began to disappear around the 1850 s.

Sites that are in this tidal area tend to be wet during the rainy season, and some are inundated with water. Based on observations it is known that the flow pattern of the river includes a type of deranged flow, which is a pattern that shows erratic river flows, mixed with swamps. From observations on the environment as well as stratigraphy of excavation boxes, it appears that the area of Bataguh site has not changed much. Agricultural activities by the recent people only slightly change the shape of the soil surface. The higher surface part of the dead river is being used to grow rubber and fruits, while the lower surface becomes rice fields. The submerged area around Pesanggrahan 7 was caused by the flow of the dead Karinyau River, which was cut off by the handil.

\section{Chronology}

The nature of the Bataguh site which was in tidal area are making it partially submerged during the rainy season. Kuta's community builds its houses using stilts constructions, so parts of the house are an important part data samples in order to explain the chronology. Furthermore, concentrated charcoal was also 
not found during the study. The wooden posts from both survei and excavation activities were selected as samples for radiocarbon dating. The result of this absolute dating can be seen in Table 4 .

Table 4. Results of ${ }^{14} \mathrm{C}$ Absolute Dating

\begin{tabular}{|c|c|c|c|c|c|}
\hline No & Year & Sample name & $\begin{array}{l}\text { Percentage } \\
\text { of modern } \\
\text { carbon (PMC) }\end{array}$ & $\begin{array}{c}\text { Age } \\
(\text { years } B P *)\end{array}$ & $\begin{array}{l}\text { Calibration } \\
\text { results } \\
\text { (calAD) }\end{array}$ \\
\hline 1 & 2017 & $\begin{array}{l}\text { Handil Alai / House pole } \\
\text { Near TP3 }\end{array}$ & $84.80 \pm 0.41$ & $1324 \pm 50$ & $611-777$ \\
\hline 2 & 2017 & Handil Kota / Pole TP2 & $90.14 \pm 0.45$ & $834 \pm 40$ & $1151-1272$ \\
\hline 3 & 2017 & $\begin{array}{l}\text { Lake in Front of } \\
\text { Pesanggrahan Tujuh / Post }\end{array}$ & $92.95 \pm 0.42$ & $588 \pm 25$ & $1302-1367$ \\
\hline 4 & 2017 & $\begin{array}{l}\text { Long Ironwood Fence Pole } \\
\text { (Survey KC) }\end{array}$ & $94,46 \pm 0.34$ & $458 \pm 20$ & $1423-1452$ \\
\hline 5 & 2017 & $\begin{array}{l}\text { Handil Kota / TP3 / Sunduk } \\
\text { Wood }\end{array}$ & $93.43 \pm 0.46$ & $546 \pm 25$ & $1390-1431$ \\
\hline 6 & 2017 & $\begin{array}{l}\text { Tiang Pagar di RT 10/ } \\
\text { Fence pole at RT } 01 \\
\text { (Survey KA) }\end{array}$ & $96.30 \pm 0,48$ & $303 \pm 15$ & $1521-1591$ \\
\hline 7 & 2018 & $\begin{array}{l}\text { Bataguh-1, Pesanggrahan } \\
\text { Sector }\end{array}$ & $80.52 \pm 0.30$ & $1740 \pm 30$ & $320-411$ \\
\hline 8 & 2018 & Bataguh-2, TP V & $81.13 \pm 0.30$ & $1680 \pm 30$ & $356-524$ \\
\hline 9 & 2018 & Bataguh-3-nibung, TP V & $82.97 \pm 0.31$ & $1500 \pm 30$ & $567-649$ \\
\hline 10 & 2019 & TP 1, Handil Alai Darat & $82.86 \pm 0.31$ & $1510 \pm 30$ & $544-645$ \\
\hline 11 & 2019 & Handil Perwira & $85.91 \pm 0.32$ & $1220 \pm 30$ & $770-905$ \\
\hline 12 & 2019 & Handil Gardu & $79.53 \pm 0.30$ & $1840 \pm 30$ & $125-256$ \\
\hline 13 & 2019 & Handil Batara & $100.00 \pm 0.37$ & $0 \pm 30$ & $1882-1926$ \\
\hline 14 & 2019 & Handil Bataguh & $71.10 \pm 0.27$ & $2740 \pm 30$ & $914-802$ BC \\
\hline 15 & 2019 & Handil Alai (Sungai Panta i) & $96.82 \pm 0.36$ & $260 \pm 30$ & $1730-1803$ \\
\hline
\end{tabular}

Note: 2017 sample calibration results using CALIB Rev.7.0.4; for 2018 and 2019 samples using Beta Cal 3.21: HPD method: SCHAL 13 (absolute dating analysis in Beta are using AMS)

The chronology of kuta on the inside of the perimeter fence can be found from nine wood pole samples analyzed in the laboratory (2017 at BATAN, 2018 at BETA Analytic Inc.; see Table 4 number 1 -- 9). Kuta's fence were represented by two wooden samples that date back to the $15^{\text {th }}-16^{\text {th }}$ centuries AD. The guardian building was represented by four samples, known to be between the $6^{\text {th }}-7^{\text {th }}$ and $12^{\text {th }}-15^{\text {th }}$ centuries AD. A sample of a pier wood shows the age of the $14^{\text {th }}$ century AD. A house inside the fortification fence was represented by two wooden samples showing the age of the $4^{\text {th }}-5^{\text {th }}$ and $7^{\text {th }}-8^{\text {th }}$ centuries AD. A wide time range is also derived from the analysis of the posts of the house outside the perimeter fence (2019 at BETA Analytic Inc.; see Table 4 numbers 10 - 15). Their age from the oldest to the youngest age are $3^{\text {rd }}$ century $A D, 7^{\text {th }}-10^{\text {th }}$ centuries $A D$, and the $18^{\text {th }}-20^{\text {th }}$ centuries AD. Carbon dating from Handil Bataguh (sample no. 14 in Table 4) which dated back to before $\mathrm{AD}$ was necessary to be re-checked.

The results of those datings taken from samples of poles for now is considered as not being able to represent the period when the buildings in the 
Bataguh site were built. Moreover, in stratigraphical considerations these poles are also cannot be attributed to the other artifacts found in the excavations, because these poles were deliberately planted as deep as 4 meters from the ground level.

\section{Interview Results}

The interview in 2017 and 2018 were mostly conducted to obtain a variety of artifacts that were found by people around Kuta Bataguh. Diggings or lootings by the community have taken place around the year 1986. Not only are the relics of ancient communities being sought, but also the wooden posts (poles), especially ironwood which is more resistant to be used as pillars for houses or other buildings (such as a bridge).

Tidal area is not an environment where ironwood can be grown. The source of ironwood for Kuta Bataguh is the Tabalien River area in Mengkatip, which is also in the upstream area of Kapuas Regency. The name of the river refers to ironwood named 'tabalien'. The Ngaju community do recognize places or forests that are considered forbidden sacred places called pahewan. The existence of pahewan is a system of local knowledge from their ancestors and passed down through the oral history / tradition as an effort to protect natural resources (Octora, 2017). People in Central Kalimantan recognize three pahewan, namely 1) Pahewan Klaru (square-shaped sandy lake) in the Klaru Katingan River; 2) Hutan Pahewan Kalawa (forest) on the border of the forest belonging to PT. Kahayan Timber, Buntui Village, and Garung Village; and 3) Hutan Pahewan Tabalien (forest) in the area of Mungku Baru Village, Rakumpit District (Octora, 2017).

As a result of lootings, the Bataguh site was damaged and a lot of important data was lost. The interviews with 'mantir', the traditional leaders, in Bataguh District obtained important information about the origin of Kuta Bataguh. How it was rediscovered namely when the making of handils in the Kupang Island area and its surroundings in 1927. When the Pantai River which flow into The Kapuas Murung was extended to handil and named Handil Alai, Kuta Bataguh had been abandoned by its inhabitants. This tidal zone was then re-occupied by the community after the canal (anjir) and handil were made as a means of transportation and irrigation.

\section{DISCUSSIONS}

\section{Characteristics of Kuta Bataguh}

Characteristic means "having specific features in accordance with certain appearances"(Badan Pengembangan dan Pembinaan Bahasa Indonesia, 2016). The results of the study in Kuta Bataguh showed that this fortified site has a different shape to other fortified settlement in southeast Kalimantan. This oval shaped settlement is certainly can be differed from other settlement in the same region. Moreover, this site is equipped with canals, and occupying vast settlement area (located in two sub-districts, Bataguh and East Kapuas) which spreading to the outer part of the fortification. The morphology of the fortification area is higher than the surrounding area. The downstream Karinyau River which flows into 
Kapuas Murung River are then branching into three tributaries, namely Kupang River, Garung River, and Alai River (Pantai River). Upstream of Karinyau River is also branching into three, one is flowing into Kapuas Murung River (Jangkit Village), the middle branch flows into Barito River, and the last one is flowing into Anjir Serapat (Figure 5). Karinyau River also has a tributary within the kuta fence.

The canal that surrounds the kuta is an artificial canal with a width of 5 meters (Figure 3). This canal nowadays is already inaccessible, only in some places is still visible due to the height difference in the land surfaces and the vegetation above it. Perennials cannot grow on this part of a land, and only grass that thrives. The roving canal serves as a boundary and defense for kuta residents. Perimeter fence made from ironwood are also arranged tightly along $3 \mathrm{~km}$, built next to the canal (the inside). Not all of the poles for this fence was able to be rediscovered. Many have been taken by the community to be used as their house poles. Some of the other poles were taken due to the addition of handil lines that pass through the central part of Kuta.

In the area inside the fence, the remains of wooden posts and holes were found. Most of the posts are ironwood, although there are other types of wood, such as selumbar, halayung, and tumih. The distribution of ironwood poles is mostly located on the banks of the Karinyau River, while other types of wood are located on the banks of the Karinyau tributary which flows within the perimeter fence. The poles and the remains of the pole holes are in a higher part of the ground than the surroundings, which known as pematang. Within the Kuta fence, there are two groups of buildings that have different functions, namely the building for supervision (the guardian house) and the building for the residence. The guard buildings were located not far from the fence and made of ironwood logs. Based on the survey results, there are seven groups of posts near the northern fortification fence, while on the south side of the river there are three groups of remaining posts.

The house-building group (area within the perimeter fence) on the north side of the river left more poles, compared to the group of buildings in the south. There are 18 groups of houses in the north of the Karinyau River using stilt constructions. Buildings that are composed of ironwood poles are mostly found on the banks of the Karinyau River, while buildings on the banks of the tributary use various wood types.

Furthermore, the house building on the site uses two types of house construction on stilts, namely kacapuri (kalang sunduk) and the one with a foundation of ironwood. The two types of construction are very different in shapes and techniques. The foundation is using one log that is split in half, then given several holes (not through) with a certain distance to put the pole of the house on it, so that it does not move (stable). Kacapuri is made by making a hole in the lower part of the wood log that acting as a supporting pole of the house, and horizontally inserting other wood in the hole to lock it. Ironwood board foundation and kacapuri are both can be used in wet land environment. The community nowadays prefers to use kacapuri construction because it requires less wood. The building that uses the ironwood board foundation is in the middle, between the Karinyau River and the guardian building, in two adjacent places. One location has four rows, and another place has two rows. The community has long known the existence of this 
foundation, and most of the boards have been removed and used as material for building houses.

Based on data from the poles, the leader residence of Kuta Bataguh (inside the fortification) is still unknown, because the poles in some groups of buildings have a relatively similar size, having a diameter of wood between 10 to $20 \mathrm{~cm}$. Nevertheless, the remains of posts and pillars of the house that has been taken away (no longer insitu) gives us clarity that the non-elite community of the kuta resides along the flow of Karinyau River (outside the roving canal). Their houses which was using stilt construction were built using wood that has lesser quality than ironwood, such as selumbar, halayung, and tumih.

Based on the shape of the fortification and the vast settlement distribution, it appears that the social organization of the community groups living in Kuta Bataguh are different from the communities in Hantapang and Mapot. Social organization of community groups has several levels starting from a simple level to a complex level, namely bands, tribes, chiefdom, and early state (Renfrew \& Bahn, 2012). Barito, Kahayan, and Kapuas were the territory of Banjar Kingdom $\left(16^{\text {th }}-1^{\text {th }}\right.$ century AD) when Schwaner made his expedition. The location of the area in those three streams are far from the center of the kingdom, so that people was still living in groups and adhere to old beliefs. Mapot and Hantapang is an example of tribe level of social organization. Then after Banjar Kingdom was controlled by the Dutch, several Dayak community leaders were appointed to lead certain regions with the title tumenggung, such as Toemenggoeng Toendan in Kahayan Hulu, Toemenggoeng Nicodemus Djaija Negara in Kuala Kapuas district, and Toemenggong Soera Pattie in Dusun Ulu, Murung, and Siang district (Hindia Belanda, 1848; Hindia Belanda, 1858; Hindia Belanda, 1868). The power of a tumenggung is equal to a chief in a chiefdom organization. Kuta which was ruled by Tumenggung Tundan on Suli Hill/ Bukit Suli (also visited by Schwaner) has a similar shape to Hantapang and Mapot. The groups that joined chiefdom in the past seemed to come from the same tribe (Tumenggung Tundan's territory in upper Kahayan which was formed by the Dutch government was consisting of two communities, Dayak Ngaju and Ot Danum).

The ruling leader in Kuta Bataguh seems to be at an even higher level, which is early state. Early state is the most complex category, which has elements that exist at the chiefdom level, added with the leader being the king or queen who has the territory of power and rule (law), already shows the characteristic pattern of urban settlements where the city center has an important role, the population is more than 5000 inhabitants, and equipped with public buildings (Renfrew \& Bahn, 2012). This assumption is supported by the data from the research results, namely 1 ). The form of the center of power and the area of Bataguh, with non-elite people was living on the outside of the fortification along the river flow both downstream and upstream; 2). The fortification in Bataguh is surrounded by canals which is the most important and most strategic location that becomes the center of power as well as the residence of the ruler; and 3) the fortification which was surrounded by the canal also serves as a public space, namely as a shelter for the community supporting kuta in the event of an enemy attack. In the fortification the community 
can survive because basic needs such as water, animal food sources (fish) and plants are fulfilled.

The limitations of the existence of abandoned objects on this site are not enough to explain who exactly the people of Kuta Bataguh are. Hantapang and Mapot clearly left the secondary burials of Ngaju people named sandung. In Bataguh, artifacts and features which were found are very common to the people of Dayak community groups living in southeast Kalimantan. However, the site's location and chronology based on absolute dating of the site have a time span between the $4^{\text {th }}$ and $16^{\text {th }}$ centuries, are hinting us to the Ngaju people as the people of Bataguh. One of the rulers in Bataguh is named Nyai Undang, a female figure known in Central Kalimantan (Kapuas) folklore. Nyai Undang ruled in Tanjung Pematang Sawang Kingdom (Bataguh) around the $14^{\text {th }}$ century AD (Putro et al., 2017). Folklore in Central Kalimantan mentions two famous female characters, Nyai Undang and Nyai Balau. Nyai Balau was also mentioned to be living inside of a fortification named Kuta Dewa which is located on the banks of the upstream Kahayan River (Schwaner, 1854). In contrast to Nyai Undang, Nyai Balau's sandung (secondary burial) still exists and is now transferred to a public graveyard in Tewah.

One of the written sources leading to an explanation of the existence of local rulers in the western Banjarmasin comes from the Portuguese Catholic Theatines, Father Antonio Ventimiglia who visited the region in the early 1690s (Smith, 2014). Ventimiglia is known to be missing, but the pastor said he had visited Ngaju group's port not far from Banjarmasin (Smith, 2014). The location of the port is not explained where, and Smith estimates that Bataguh is the port that was visited by Ventimiglia.

Bataguh's existence was also mentioned by Baier, a German priest who was a visiting lecturer at STT-GKE Banjarmasin, in one of his writings (Baier, 2002). Baier had visited the site while on duty in Banjarmasin. According to him, Ngaju in the early 1700s had traded directly with Singapore, sometimes even hijacking merchant ships at sea. The trade carried out by the Ngaju community ended around 1826 (Baier, 2002). Ngaju people at that time knew slavery and used their slaves among others to build long houses/ rumah panjang (a large house surrounded by fences of ironwood). The slaves around the 1800s came from outside Kalimantan Island (Baier, 2002). The existence of Bataguh is also associated with the Kingdom of Tanjungpura which became an important trading center in Kalimantan in addition to Brunei, and Lawai (as mentioned in Portuguese sources) (Smith \& Smith, 2011). This opinion still requires additional data because it is believed by experts that Tanjungpura is in the region of West Kalimantan, not in South Kalimantan (southeast).

The situation along the Kapuas River (Central Kalimantan) was also reported by Schwaner who carried out the expedition around the 1840s. Schwaner still sees some settlements using a perimeter fence of ironwood which he refers to as kotta in Kapuas Murung area (Schwaner, 1853), but none of the kotta that was mentioned by Schwaner is named Bataguh or Pematang Sawang. Many kuta were also found by Schwaner along the Kahayan River. The two groups that are hostile to each other are Dayak Ngaju and Ot Danum. Settlements with a complex defense system is made to ensure the safety and life continuity of each group. Headhunting 
practices can finally be stopped after the Tumbang Anoi agreement was agreed. Tumbang Anoi was initiated by the Netherlands and attended by all Dayak community representatives in Kalimantan in 1894.

The rulers of Bataguh occupy an area surrounded by canals. Based on the thickness of peat at the test pit trench which is about $50 \mathrm{~cm}$, and by using the calculation of peat layer formation as thick as $30 \mathrm{~cm}$ per 100 years then it can be estimated that the canal waters began to disappear around the 1850s. Schwaner's expedition took place from 1843 to 1847, but the existence of this kuta has not been reported. News from Portuguese Catholic priests mentioned that in the late 1600s, in the western part of Banjarmasin there was a local ruler Dayak Ngaju who did direct trade with outside world. Ngaju's trade was no longer mentioned (ended) in 1826. Based on this description, it can be assumed that the existence of Dayak Ngaju territory in the tidal land of Bataguh began around the $5^{\text {th }}$ century AD and ended in the early 19th century AD. The ups and downs of authorities in Bataguh are not yet known.

\section{CONCLUSION}

The existence of Kuta Bataguh, which has a centered settlement pattern, and community settlements (around the fortification) along the Karinyau River indicate that the level of life on this site was small powered community but had reached a higher organizational level. The construction of the Kuta surrounded by ironwood fences and artificial canals illustrates that the leaders in Bataguh had had great strength to be able to get the energy and materials to make up the perimeter fence. The maintenance of canals and perimeter fences also requires separate costs, as well as labor to maintain security around Kuta, which is evidence of the existence of complex social organization of community groups.

The selection of locations in the tidal area also hints that the $k u t a$ supporters have been able to manage the surrounding nature to meet their daily living needs. Bataguh with a power center equipped with a dual defense system (canals and fortifications), and the spread of non-elite people housing along the Karinyau River, can be included in the early state category, with the possibility that their territory is not only limited in the Karinyau River. Further research is needed to be able to explain the entire region and the ups and downs of authority in Bataguh.

\section{ACKNOWLEDGEMENTS}

Acknowledgements are addressed to several parties involved in the Kuta Bataguh research, specifically Regional Agency for Archaeological Research in South Kalimantan Province, Central Kalimantan Education and Culture Office, Heritage Conservation Office of East Kalimantan, and all team members. 


\section{BIBLIOGRAPHY}

Akbar, A. (2012). Persamaan Allometrik Untuk Menduga Kandungan Karbon Jenis Meranti (Shorea teysmaniana) Di Hutan Alam Rawa Gambut Kalimantan Tengah. Jurnal Penelitian Sosial Dan Ekonomi Kehutanan, 9(1), pp. 1-11. https://doi.org/10.20886/jsek.2012.9.1.1-11

Badan Pengembangan dan Pembinaan Bahasa Indonesia. (2016). Kamus Besar Bahasa Indonesia. Retrieved from kbbi.kemdikbud.go.id

Baier, M. (2002). Contributions to Ngaju history, 1690-1942. Borneo Research Bulletin, 33, pp. 75-81.

Balai Arkeologi Kalimantan Selatan. (2017). Laporan Penelitian Kuta Bataguh (Tahap 1), Kabupaten Kapuas, Kalimantan Tengah. Banjarbaru: Tim Penelitian.

Balai Arkeologi Kalimantan Selatan. (2018). Laporan Penelitian Kuta Bataguh (Tahap 2), kabupaten Kapuas, Kalimantan Tengah. Banjarbaru: Tim Penelitian.

Balai Arkeologi Kalimantan Selatan. (2019). Laporan Penelitian Kuta Bataguh (Tahap 3), Kabupaten Kapuas, Kalimantan Tengah. Banjarbaru: Tim Penelitian.

Bintarto, R., \& Hadisumarno, S. (1991). Metode Analisa Geografi. Jakarta: LP3ES.

Hindia Belanda. (1848). Almanak en Naaregister voor Het Schrikkel Jaar 1848. Batavia: Ter lands Drukkerij.

Hindia Belanda. (1858). Almanak en Naamregister van Nederlandsch Indie voor 1858. Batavia: Ter lands Drukkerij.

Hindia Belanda. (1868). Regerings Almanak voor Nederlandsch Indie 1868. Batavia: Landsdrukkerij.

Hodder, I., \& Hutson, S. (2003). Reading The Past: Current Approaches to Interpretation in Archaeology (Third edit). United Kingdom: Cambridge University Press.

Lucas, R. E. (1982). Organic Soils (Histosol), Formation, Physical and Chemical Properties and Management for Crop Prodiction. Research Report. 435 Farm Science, Michigan State University.

Maimunah, S. (2014). Uji Viabilitas Dan Skarifikasi Benih Beberapa Pohon Endemik Hutan Rawa Gambut Kalimantan Tengah. Journal Hujan Tropis, 2(1), 71-76.

Octora, M. (2017). The Local Knowledge of Dayaknese: Case Study of Pahewan Tabalean. Advance in Social Science, Education and Humanities Research, 138, pp. 104-107. https://doi.org/10.2991/icocspa-17.2018.29

Putro, H. P. N., Anis, M. Z. A., \& Mansyur. (2017). The Lost City Menelusuri Jejak Nyai Undang Dari Kuta Bataguh Dalam Memori Suku Dayak Ngaju. Yogyakarta: Penerbit Ombak. 
Rahu, A. A., Hidayat, K., Ariyadi, M., \& Hakim, L. (2013). Ethnoecology of Kaleka: Dayak's Agroforestry in Kapuas, Central Kalimantan Indonesia. Research Journal of Agriculture and Forestry Sciences Res. J. Agriculture and Forestry Sci, 1(8), pp. 2320-6063. Retrieved from http://luchmanhakim.lecture.ub.ac.id/files/2013/03/RAhu-KliwonAryadi-HAkim-ISCA.pdf

Renfrew, C., \& Bahn, P. G. (2012). Archaeology Theories, Methodes and Practice. London: Thames and Hudson.

Schwaner, C. A. L. . (1854). Borneo Beschrijving van Het Stroomgebied van Den Barito.

Schwaner, C. A. L. M. (1853). Beschrijuing van het stroomgebied van den Barito en reizen langs eenige voorname rivieren van het zuid-oostelijk gedeelte van dat eiland (Vol. 1). PN van Kampen.

Simanjuntak, H. Truman, D. (2008). Metode Penelitian Arkeologi. Jakarta: Pusat Penelitian dan Pengembangan Arkeologi Nasional.

Smith, F. A. (2014). Problematic Plagiarism and Careless Cartography: Valentyn's Borneo and the Lost Roman Catholic mission in South Borneo at the end of the seventeenth century. Borneo Research Bulletin, 45, pp.1-11.

Smith, F. A., \& Smith, H. F. (2011). A shadowy state in Borneo: where was Tanjungpura? Borneo Research Bulletin, 42(89-103). Retrieved from http://www.thefreelibrary.com/A+shadowy+state+in+Borneo\%3A+where +was+Tanjungpura\%3F-a0290733356

Sunarningsih. (2017a). Karakter Pemukiman Lahan Basah Abad VI - XV Masehi di Daerah Aliran Sungai (DAS) Barito. Kapata Arkeologi, 13(1), p. 109. https://doi.org/10.24832/kapata.v13i1.406

Sunarningsih. (2017b). Kuta Hantapang, Benteng Masyarakat Ngaju di Kalimantan Tengah. Kindai Etam: Jurnal Penelitian Arkeologi, 3(1), pp. 54-81.

Sunarningsih. (2018a). Pemukiman Masyarakat Ngaju di Hulu Daerah Aliran Sungai Kahayan Dari Abad ke-4 hingga ke-19 Masehi. Naditira Widya, 12(1), p. 23. https://doi.org/10.24832/nw.v12i1.296

Sunarningsih. (2018b). Ragam Bentuk Artefak Kayu Situs Cindai Alus, Kabupaten Banjar, Kalimantan Selatan (the Forms of Wooden Artifacts From Cindai Alus, in the Regency of Banjar, South Kalimantan Province). Kindai Etam: Jurnal Penelitian Arkeologi, 4(1), 17-40. https://doi.org/10.24832/ke.v4i1.34

Sunarningsih. (2019). Hunian Berbentuk (Kuta) Mapot: Studi Bentuk , Simbol , Dan Kronologi. Kindai Etam: Jurnal Penelitian Arkeologi, 5(1), pp. 13-26. https://doi.org/10.24832/ke.v5i1.50 
This page was left intentionally blank. 
This page was left intentionally blank. 